\title{
A DISORDER OF BLOOD COAGULATION IN SYSTEMIC LUPUS ERYTHEMATOSUS 1, 2
}

\author{
By STANLEY L. LEE AND MARTIN SANDERS with THE TECHNICAL ASSISTANCE OF \\ HELEN M. KAHNY
}

(From the Department of Hematology, Mount Sinai Hospital, New York, N. Y.)

(Submitted for publication June 13, 1955; accepted August 31, 1955)

Conley and Hartmann $(1,2)$ have reported the existence of a disorder of blood clotting in two patients with systemic lupus erythematosus. In both cases there were severe hemorrhagic symptoms associated with prolongation of the clotting time and the presence of a substance interfering with the interaction of thromboplastin and prothrombin.

Previous studies in this laboratory (3) had suggested that the $\mathrm{L}$. E. cell factor required thromboplastin or some component thereof, in order to act on leukocytes.

A possible relationship between these two sets of data suggested itself: the L. E. cell factor, reacting in some way with thromboplastin, could inhibit thromboplastin in turn from reacting with prothrombin. If this hypothesis were valid, every blood containing the L. E. cell factor should show impaired thromboplastin function. The clotting disorder described might thus be a characteristic feature of systemic lupus.

To test this hypothesis, a systematic survey of blood coagulation in every available patient with systemic lupus erythematosus was undertaken.

\section{MATERIALS AND METHODS}

Forty-three consecutive patients with systemic lupus erythematosus were studied. Most of these were from the Wards and the Out-Patient Department of The Mount Sinai Hospital; some were private patients or patients in other hospitals. ${ }^{3}$

\footnotetext{
1 Supported by a grant (A-221) from the U. S. Public Health Service, National Institute of Arthritis and Metabolic Diseases, and the A. A. List and Anna Ruth Lowenberg Funds.

2 Presented (in part) at the Annual Meeting of the Eastern Section of the American Federation for Clinical Research, Boston, January, 1954.

${ }^{3}$ We are indebted to S. R. Karelitz, M. Levitt, S. Miller, B. S. Oppenheimer, and N. Rosenthal and to the staffs of the Brooklyn Regional Center of the Veterans' Administration, Harlem Hospital, Jewish Memorial Hospital and the New York Hospital for the opportunity to study individual patients included in this study.
}

All procedures were performed on fresh blood drawn through a clean venipuncture into siliconized equipment.

The following studies were performed on each patient:

1) L. E. cell preparation: In each patient the L. E. cell was demonstrated by the clotted blood technique (4) or by incubation of serum with washed normal leukocytes (5).

2) Platelet counts were done by the method of Ottenberg and Rosenthal (6).

3) Whole blood clotting times were done by the modified Lee-White method using one tube of eleven $\mathrm{mm}$. diameter with incubation at $37^{\circ} \mathrm{C}$.

4) Plasma clotting times were measured by the method of Quick (7), using both platelet-rich and platelet-poor plasmas. In every case platelet-rich plasma was obtained by sedimentation of red cells without centrifugation. Platelet-poor plasma was prepared by centrifugation in silicone-coated tubes for 30 minutes at 4,500 rpm., in the Sorvall Angle Centrifuge at room temperature.

5) Prothrombin times were performed by the onestage method of Quick (7).

6) The residual serum prothrombin activity was determined by the method of Stefanini and Crosby (8).

Where abnormalities were found, some or all of the following tests were performed:

1) The presence of an anticoagulant was shown by the ability of the blood or plasma to prolong the coagulation time of normal blood or plasma.

2) Thrombin generation tests were done by a modification of the method of Pitney and Dacie (9):

a) One ml. of platelet-rich plasma obtained without centrifugation was added to $1 \mathrm{ml}$. of $0.025 \mathrm{M} \mathrm{CaCl}_{2}$ and $0.25 \mathrm{ml}$. of normal saline or test material in a glass tube.

b) The reaction mixture was allowed to incubate at $37^{\circ} \mathrm{C}$. and at $1-$ minute intervals $0.1-\mathrm{ml}$. aliquots were added to $0.4 \mathrm{ml}$. fibrinogen solution.

c) The fibrinogen used was Bovine Fraction I Fibrinogen (Armour) in a concentration of $1,000 \mathrm{mgm}$. per $100 \mathrm{ml}$. of saline. Since the material contains about 50 per cent by weight of sodium citrate the actual concentration of the fibrinogen solution was in the neighborhood of $500 \mathrm{mgm}$. per $100 \mathrm{ml}$.

d) The calibration was obtained by adding $0.1-\mathrm{ml}$. aliquots of serial dilutions of topical thrombin (ParkeDavis) to $0.4-\mathrm{ml}$. portions of the fibrinogen solution. The thrombin unitage of a particular sample of plasma has been expressed as N.I.H. units per ml. 
TABLE I

Coagulation profile of cases showing abnormalities of clotting

\begin{tabular}{|c|c|c|c|c|c|c|}
\hline Patients & $\begin{array}{l}\text { Whole } \\
\text { blood } \\
\text { clotting } \\
\text { time }\end{array}$ & $\begin{array}{l}\text { Plasma cl } \\
\text { Platelet- } \\
\text { rich }\end{array}$ & $\begin{array}{l}\text { ing time } \\
\text { Platelet- } \\
\text { poor }\end{array}$ & $\begin{array}{c}\text { Prothrombin } \\
\text { time }\end{array}$ & $\begin{array}{l}\text { Serum } \\
\text { proth. }\end{array}$ & Platelets/mm. ${ }^{2}$ \\
\hline Normal valuest & $\begin{array}{l}5-10 \\
\text { min. }\end{array}$ & $\begin{array}{c}100-180 \\
\text { sec. }\end{array}$ & $\begin{array}{c}150-250 \\
\text { sec. }\end{array}$ & $\begin{array}{c}12-14 \\
\text { sec. }\end{array}$ & $\begin{array}{c}\text { Over } \\
22 \text { sec. }\end{array}$ & $\begin{array}{l}150,000- \\
300,000\end{array}$ \\
\hline \multicolumn{7}{|c|}{ Severely affected } \\
\hline $\begin{array}{l}\text { E. L. } \\
\text { R.S. } \\
\text { M.M. } \\
\text { B. V. } \\
\text { B. L. } \\
\text { J.I. } \\
\text { J. H. }\end{array}$ & $\begin{array}{r}30 \\
21 \\
10 \\
15 \\
14 \\
12 \\
6\end{array}$ & $\begin{array}{c}330 \\
* \\
* \\
300 \\
270 \\
195 \\
110\end{array}$ & $\begin{array}{r}1,550 \\
900 \\
700 \\
720 \\
640 \\
750 \\
780\end{array}$ & $\begin{array}{l}25.4 \\
20.2 \\
17.8 \\
12.8 \\
14.5 \\
16.5 \\
14.8\end{array}$ & $\begin{array}{r}30 \\
9 \\
43 \\
32 \\
27 \\
38 \\
24\end{array}$ & $\begin{array}{r}170,000 \\
8,000 \\
22,000 \\
80,000 \\
225,000 \\
135,000 \\
210,000\end{array}$ \\
\hline $\begin{array}{l}\text { G. R. } \\
\text { M. G. } \\
\text { B.S. } \\
\text { R. V. } \\
\text { R. M. }\end{array}$ & $\begin{array}{r}8 \\
6 \\
7 \\
12 \\
10\end{array}$ & $\begin{array}{l}125 \\
170 \\
105 \\
250 \\
180\end{array}$ & $\begin{array}{l}400 \\
190 \\
265 \\
270 \\
225\end{array}$ & $\begin{array}{l}18.2 \\
14.0 \\
20.1 \\
13.6 \\
18.9\end{array}$ & $\begin{array}{l}50 \\
30 \\
69 \\
32\end{array}$ & $\begin{array}{l}255,000 \\
170,000 \\
100,000 \\
120,000 \\
140,000\end{array}$ \\
\hline
\end{tabular}

* Severe thrombocytopenia.

† Stated normal values represent experience in this laboratory of at least 500 determinations of each type.

3) Thromboplastin dilution studies were performed by making serial dilutions of rabbit brain thromboplastin (Difco) in saline. One-tenth $\mathrm{ml}$. of each dilution was added in turn to $0.1 \mathrm{ml}$. of test plasma and $0.1 \mathrm{ml}$. of $0.025 \mathrm{M} \mathrm{CaCl}{ }_{2}$ and clotting times measured as in the Quick prothrombin test.

4) The thrombin dilution tests were done by making serial dilutions of Topical Thrombin (Parke-Davis) from 100 to 0.5 N.I.H. units per $\mathrm{ml}$. One-tenth $\mathrm{ml}$. of each dilution was then added in turn to $0.1 \mathrm{ml}$. of test plasma and clotting time measured.

5) Protamine titrations were performed by making serial dilutions of protamine sulfate, adding platelet-rich oxalated plasma and $0.025 \mathrm{M} \mathrm{CaCl}_{2}$, and measuring clotting time.
6) Fractionation of plasma was carried out by the method of Svensson (10). The identity of plasma fractions obtained was confirmed by filter paper electrophoresis.

7) Thromboplastin generation tests were carried out according to the method of Biggs and Douglas (11), modified in that barium-sulfate-adsorbed plasma was used as a source of anti-hemophilic globulin instead of aluminatreated plasma.

\section{RESULTS}

Of the forty-three patients with systemic lupus erythematosus who were studied, thirty-one showed no abnormality of the coagulation mecha-

TABLE II

Thrombin generation-Abnormal cases

(This is the table from which Figure 1 was prepared)

\begin{tabular}{|c|c|c|c|c|c|c|c|c|c|c|c|c|c|c|}
\hline $\begin{array}{c}\text { Time } \\
\text { interval } \\
(m i n .)\end{array}$ & 1 & 2 & 3 & 4 & 5 & 6 & 7 & 8 & 9 & 10 & 11 & 12 & 13 & 14 \\
\hline $\begin{array}{l}\text { M. M.* } \\
\text { J. I.* } \\
\text { M. G. } \\
\text { G. R. } \\
\text { E. L.* } \\
\text { R. V. } \\
\text { B. S. } \\
\text { R.S. S.* } \\
\text { J. H.* } \\
\text { B. L.* }\end{array}$ & $\begin{array}{l}\mathbf{0} \\
\mathbf{0} \\
\mathbf{0} \\
\mathbf{0} \\
\mathbf{0} \\
\mathbf{0} \\
\mathbf{0} \\
\mathbf{0} \\
\mathbf{0} \\
\mathbf{0}\end{array}$ & $\begin{array}{l}0 \\
0 \\
0 \\
0.4 \\
0 \\
0 \\
0 \\
0 \\
0 \\
0\end{array}$ & $\begin{array}{l}0 \\
0.2 \\
0 \\
0.4 \\
0 \\
0.2 \\
0.6 \\
0 \\
0 \\
0\end{array}$ & $\begin{array}{l}0 \\
0.3 \\
0 \\
1.3 \\
0 \\
0.7 \\
1.0 \\
0 \\
0.4 \\
0.1\end{array}$ & $\begin{array}{l}0 \\
0.4 \\
0.1 \\
1.9 \\
0 \\
1.0 \\
1.6 \\
0 \\
0.9 \\
0.4\end{array}$ & $\begin{array}{l}0 \\
0.5 \\
0.2 \\
2.0 \\
0 \\
2.4 \\
0.2 \\
0 \\
2.4 \\
0.7\end{array}$ & $\begin{array}{l}0.1 \\
0.9 \\
0.4 \\
1.7 \\
0 \\
3.3 \\
1.6 \\
0 \\
2.5 \\
1.6\end{array}$ & $\begin{array}{l}0.2 \\
1.9 \\
1.3 \\
1.6 \\
0 \\
2.7 \\
0.6 \\
0 \\
1.2 \\
3.8\end{array}$ & $\begin{array}{l}0.3 \\
2.2 \\
0.3 \\
0.9 \\
0 \\
1.9 \\
0.4 \\
0 \\
0.7 \\
2.8\end{array}$ & $\begin{array}{l}0.4 \\
1.2 \\
0.1 \\
0.8 \\
0.4 \\
1.0 \\
0.2 \\
0 \\
0.4 \\
2.4\end{array}$ & $\begin{array}{l}2.7 \\
0.9 \\
0 \\
0.4 \\
0.3 \\
0.4 \\
0.1 \\
0 \\
0.1 \\
1.3\end{array}$ & $\begin{array}{l}0.8 \\
0.5 \\
0 \\
0.2 \\
0.3 \\
0.1 \\
0 \\
0 \\
0.7\end{array}$ & $\begin{array}{l}0.9 \\
0.2 \\
0 \\
0.2 \\
0.3 \\
0.2 \\
0.1 \\
0 \\
0 \\
0.2\end{array}$ & $\begin{array}{l}0.2 \\
0.2 \\
0 \\
- \\
0 \\
0.1 \\
0 \\
0 \\
0\end{array}$ \\
\hline
\end{tabular}

Normal results:

1) Peak at 4 to $6 \mathrm{~min}$.

2) Thrombin generated at maximum 2 to 8.7 units.

3) Measurable amounts appeared at 2 minutes in every case and fell off rapidly by 10 minutes.

- Patients in whom an anticoagulant was demonstrated (see Table III).; 
nism. The results obtained in the remaining twelve patients are discussed below.

\section{1) Whole Blood Clotting Time (Table I)}

In four patients the whole blood clotting time was definitely prolonged. In the remaining eight it was normal or borderline.

\section{2) Plasma Clotting Time (Table I)}

The clotting time of recalcified plasma prepared from oxalated whole blood without centrifugation was prolonged in six.

However, when the plasma was made plateletpoor the recalcification time became prolonged in three additional patients.

\section{3) Prothrombin Times (Table I)}

The prothrombin time of eight of the twelve patients was prolonged. In each case having a prolonged prothrombin time, mixture with equal parts of normal plasma failed to yield complete correction of the abnormality.

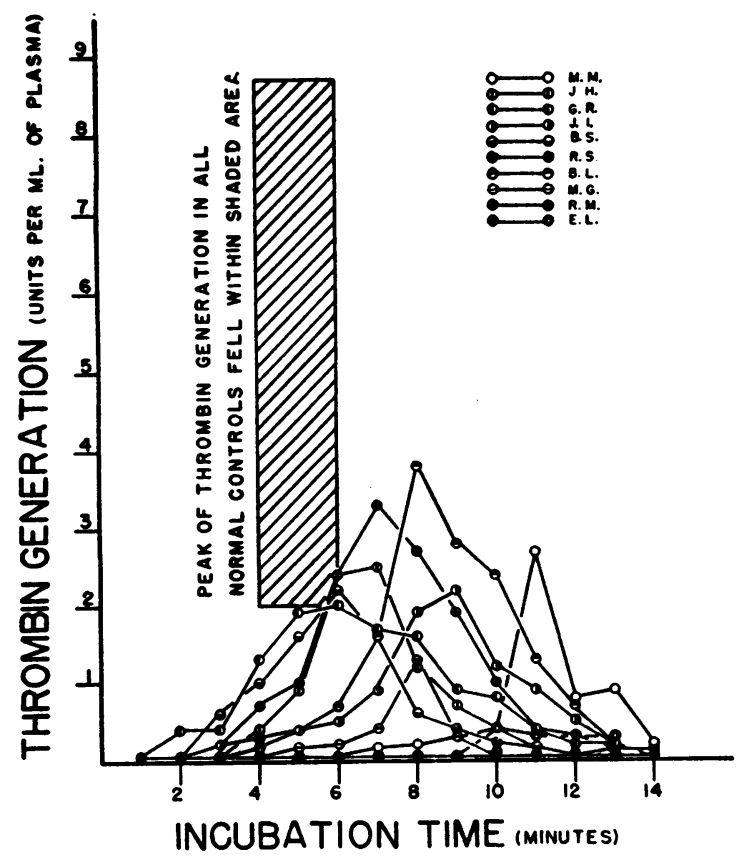

Fig. 1. Demonstrating Delay in Thrombin Generation during Clotrtivg of Plasmas Whose Serum Prothrombin at the End of One Hour Was Norual

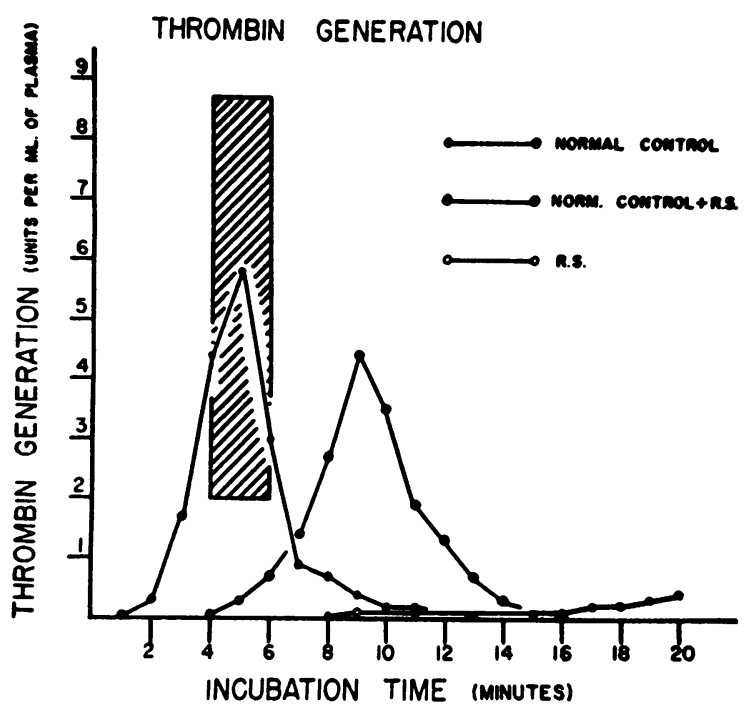

Fig. 2. Thrombin Generation of Plasma of Patient with Severe Thrombocytopenia and Anticongulant

Shaded area represents range of peak thrombin production of $\mathbf{5 0}$ control plasmas. R.S. plasma alone shows almost no thrombin generation. Mixture of 80 per cent normal, 20 per cent R.S. shows delay due to anticoagulant, although total thrombin generated (i.e., prothrombin consumed) is now normal.

\section{4) Serum Prothrombin Activity (Table I)}

All patients had normal consumption of prothrombin with the exception of R.S., who at the time the test was performed had a platelet count of $8,000 / \mathrm{mm}^{3}$.

\section{5) Platelets (Table I)}

The platelet count was markedly diminished in two patients, moderately so in five, and normal in five.

6) Thrombin Generation Test (Table II, Figure 1)

The thrombin generation test was performed on ten of the twelve patients, and on 50 control subjects. In three of the patients the formation of thrombin was delayed and the maximum amount generated was below normal. In five others, while there was a delay in thrombin formation, the maximum amount generated was normal. In the remaining two patients, the thrombin generation curves were low normal.

In patient R. S., who had a severe thrombocyto- 
TABLE III

Recalcification times using plasma mixtures*

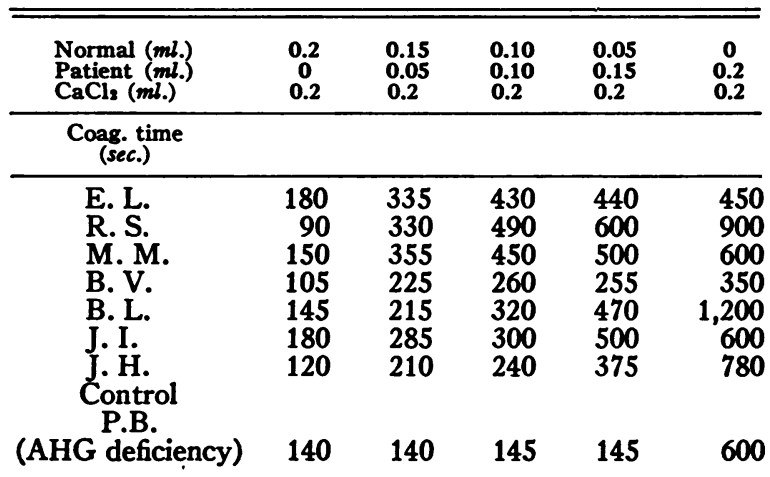

* Clotting times after recalcification of mixtures of fresh plasma from affected patients with fresh normal plateletrich plasma. Prolongation of the clotting time of normal plasma by small proportions of the abnormal plasmas is noted.

penia, thrombin generation was both delayed and impaired. Figure 2 demonstrates the partial correction of thrombin generation by the addition of normal platelet-rich plasma. A mixture containing only 20 per cent of R. S. plasma delayed thrombin generation in the normal plasma although the peak of formation of thrombin was not materially decreased.

7) Demonstration of the Anticoagulant (Table III)

In all patients in whom a prolonged whole blood or plasma clotting time was observed, a circulat- ing anticoagulant was demonstrated by mixtures with normal whole blood or plasma.

\section{8) Thromboplastin Dilutions (Table IV, Figure 3)}

Thromboplastin dilution studies were performed on seventy-five normal subjects and gave values shown in the shaded area of this chart. In eleven of the twelve patients under discussion there was definite prolongation of the clotting time of plasma to which diluted thromboplastin was added. Values within the normal range were obtained from one patient in this group.

\section{9) Thrombin Dilutions}

In the same seven patients in whom the anticoagulant was demonstrated, thrombin dilution studies were carried out. Abnormal findings were present in three patients. (M. M., R. S., and B. L.) When the plasma of M. M., and R. S., were stored at $4^{\circ} \mathrm{C}$. overnight, their antithrombin activity had disappeared, although anticoagulant activity was unimpaired. In the case of B. L., however, both anticoagulant and anti-thrombin activity had disappeared after overnight refrigeration.

\section{0) Protamine Titration}

This procedure was carried out on three plasmas showing anticoagulant activity. No heparin-like activity could be demonstrated.

TABLE IV

Thromboplastin dilutions-Abnormal cases

(This is the table from which Figure 3 was prepared)

\begin{tabular}{|c|c|c|c|c|c|c|c|}
\hline \multirow{2}{*}{$\begin{array}{l}\text { Coag. } \\
\text { times }\end{array}$} & \multirow{2}{*}{$\underset{\text { strength }}{\text { Full }}$} & \multicolumn{4}{|c|}{$\begin{array}{l}\text { Dilutions of Thromboplastin } \\
\text { (Rabbit-brain dehydrated, Difco) } \\
\text { Times are in seconds }\end{array}$} & \multirow[b]{2}{*}{$1: 32$} & \multirow[b]{2}{*}{$1: 64$} \\
\hline & & $1: 2$ & $1: 4$ & $1: 8$ & $1: 16$ & & \\
\hline $\begin{array}{l}\text { M. M.* } \\
\text { J. I.** } \\
\text { M.G. } \\
\text { G. R. } \\
\text { E. L.* } \\
\text { R. V. } \\
\text { B. V.* } \\
\text { B. S. } \\
\text { R. M. } \\
\text { R. S.* } \\
\text { J. H.* } \\
\text { B. L.* }\end{array}$ & $\begin{array}{l}17.8 \\
16.5 \\
14.0 \\
18.2 \\
25.4 \\
13.6 \\
12.8 \\
20.1 \\
18.9 \\
20.2 \\
14.8 \\
14.5\end{array}$ & $\begin{array}{l}18.2 \\
18.0 \\
15.6 \\
19.1 \\
27.1 \\
14.4 \\
14.0 \\
22.0 \\
19.3 \\
23.0 \\
16.4 \\
16.2\end{array}$ & $\begin{array}{l}19.1 \\
19.4 \\
17.6 \\
21.2 \\
30.0 \\
17.3 \\
18.4 \\
25.0 \\
22.3 \\
30.2 \\
18.8 \\
20.5\end{array}$ & $\begin{array}{l}21.9 \\
21.8 \\
21.8 \\
26.7 \\
45.4 \\
21.6 \\
26.0 \\
31.3 \\
25.6 \\
39.8 \\
21.4 \\
27.4\end{array}$ & $\begin{array}{l}25.8 \\
25.0 \\
26.2 \\
34.3 \\
78.1 \\
30.8 \\
30.5 \\
42.2 \\
31.5 \\
50.2 \\
30.6 \\
33.4\end{array}$ & $\begin{array}{r}31.6 \\
30.0 \\
33.2 \\
43.2 \\
110.0 \\
37.6 \\
46.0 \\
58.1 \\
34.2 \\
63.1 \\
36.0 \\
41.0\end{array}$ & $\begin{array}{r}45.2 \\
35.0 \\
54.6 \\
52.1 \\
150.2 \\
\\
\\
75.2 \\
46.4 \\
78.2 \\
45.8 \\
50.8\end{array}$ \\
\hline Normal range & $11.5-14.5$ & $12.0-15.0$ & $12.5-16.0$ & $14-17.5$ & $16-22$ & $20-30$ & $22-37$ \\
\hline
\end{tabular}

* Patients in whom an anticoagulant was demonstrated (see Table III).

† Equals one-stage prothrombin time. 


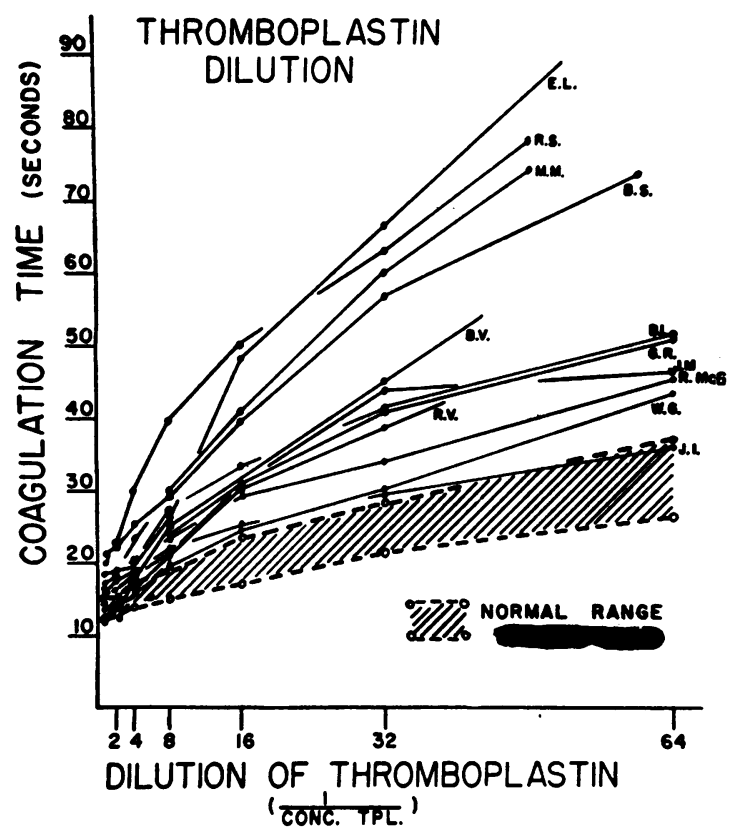

Fig. 3. Demonstrating Increased Resistance to the Action of Thromboplastin on the Part of 11 of 12 Abnormal Plasmas Studied

In this range of thromboplastin concentrations, plasmas with deficiencies of thromboplastic factors give normal results.

\section{1) Thromboplastin Generation}

It will be noted from Table I and Table III that in patient $\mathrm{J}$. I. in whom a prolonged clotting time and anticoagulant were demonstrated the thromboplastin dilution tests were within normal limits. When a thromboplastin generation test was performed using J. I.'s plasma, it showed impaired formation of thromboplastin. When the same test was performed on plasma of E. L., and M. M., who were among the most severely affected in this group, the generation of thromboplastin was within normal limits.

\section{2) Plasma Fractionation}

Plasma from patient E. L. was found to have the highest titer of anticoagulant activity in this series $(1: 128) .4$ Aliquots of fresh plasma from this patient were fractionated by the method of Svensson (10), after which whole plasma and each of the fractions obtained were tested for anti-

4 Plasma from E. L., when diluted with normal plasma to a final concentration of $1: 128$, showed significant prolongation of recalcification time as compared with the normal plasma alone. coagulant activity. The fraction precipitated between 25 and $331 / 3$ per cent saturation of $\left(\mathrm{NH}_{4}\right)_{2}$ $\mathrm{SO}_{4}$ was the only active one. This fraction showed mainly gamma globulin motility in paper electrophoresis.

\section{DISCUSSION}

From these data it would seem that seven of the forty-three patients studied showed distinct abnormality of blood coagulation. This abnormality (Table I) took roughly the same form in all seven, although it varied in degree. Marked delay of clotting of platelet-poor plasma was found in all. Most had some prolongation of whole blood coagulation time and of one-stage prothrombin time.

Although all but one (R. S.) showed apparently normal prothrombin conversion at the end of one hour, thrombin generation tests (Table II, Figure 1). showed that a delay in conversion of prothrombin was present in all of the six so studied.

Plasma mixture experiments performed on the bloods of these patients showed the presence of circulating anticoagulants in all seven. It then became important to demonstrate the sites of action of these anticoagulants. In the schema of blood coagulation, three major reactions occur: 1) The formation of thromboplastin by interaction of platelets, calcium and plasma thromboplastin precursor substances; 2 ) the conversion of prothrombin to thrombin by the action of thromboplastin in the presence of the two accelerator substances; and 3 ) the formation of fibrin from fibrinogen under the influence of thrombin. In only the third of these reactions is there any extensive knowledge of either the kinetics of the reaction or the nature of the reacting substances. Nevertheless it is possible to detect gross interference with any one of the three reactions.

Addition of varying amounts of pre-formed thrombin to a test plasma by-passes the first two reactions. Marked delay in fibrin formation (by comparison with normal controls and in the presence of normal fibrinogen concentrations) indicates the presence of a substance which inhibits the action of thrombin.

Similarly, addition of varying amounts of preformed thromboplastin to a test plasma by-passes the first reaction. A plasma which demonstrated delayed fibrin formation under the conditions of 
this test may contain a substance interfering with either the second or the third reaction (if it can be shown that the defect is not due to a deficiency of any necessary substances).

By means of the thromboplastin generation test of Biggs and Douglas (11), it is possible to detect the presence of a substance interfering with the formation of thromboplastin-the first reaction of the clotting process. In this test, prothrombinfree plasma (containing some of the plasma thromboplastin precursors, but not all) is incubated with platelets and serum (containing the remaining plasma thromboplastin precursors) in the presence of calcium. At stated intervals, aliquots are removed from the reaction mixture and tested for thromboplastin potency against normal plasma. In our studies normal platelets were employed, with serum and barium-sulfate-treated plasma from the patient in question. It was possible so to manipulate the concentrations of the reagents that the critical dilution of the anticoagulant (determined previously by mixture with normal plasma) was not exceeded in the first reaction mixture, but was exceeded in the second stage of the test. In this way, although the end point of this, as of all coagulation tests, is the production of fibrin, the activity of the anticoagulant could be confined to the first coagulation reaction-the formation of thromboplastin.

The foregoing paragraphs are admittedly oversimplifications. The "thromboplastin" measured in the thromboplastin generation test of Biggs and Douglas is not the same substance as the active ingredient of dehydrated rabbit brain. And addition of thrombin to plasma does not completely by-pass the first stages of coagulation: Alexander, Goldstein, Rich, Le Bolloc'h, Diamond, and Borges (12) have shown that the anti-hemophilic factor of plasma is consumed when this reaction occurs. Nevertheless, this schema, in a crude way, allows one to characterize a circulating anticoagulant.

In six of the seven patients with circulating anticoagulants, increased resistance to the action of thromboplastin was noted (Table IV). One (J. I., Figure 3) showed insufficient evidence of this type of anti-thromboplastic activity. However, thromboplastin generation in her blood was definitely impaired, whereas thromboplastin generation of two of the most severely affected of the other patients (E. L. and M. M.) was within normal limits. On the other hand, increased anti-thrombin activity was demonstrated on only one patient (B. L.) of the seven. In this patient the anti-thrombin could have been responsible for all the abnormal findings.

In the case of patient J. I., then, the circulating anticoagulant apparently acted to prevent the formation of thromboplastin. In patients E. L., R. S., M. M., J. H., and B. V., the anticoagulants seemed to act to prevent the action of thromboplastin with prothrombin. In patient B. L., there was in addition evidence of interference with the action of thrombin. ${ }^{5}$

In addition to these patients, five of the remaining showed minor coagulation defects (Tables I and II, Figure 1), and an increased resistance to the action of thromboplastin. (Table IV, Figure 3 ). None of these five had sufficient prolongation of clotting times of blood or plasma to allow proof of the existence of circulating anticoagulants. However it seems probable that the abnormalities observed in their blood specimens were due to lesser degrees of the same disorder found in the seven cases already discussed.

Of forty-three patients studied, twelve showed disorders of coagulation other than thrombocytopenia. One of these had a circulating anticoagulant active in the first stage; eleven showed interference with the action of thromboplastin (second stage). Of these, the anticoagulant activity may have been due to an anti-thrombin in one.

\section{Clinical significance}

Only four of the forty-three patients studied had ever had hemorrhagic manifestations. All of these four had severe thrombocytopenia at one time during the course of their disease. The relationships among thrombocytopenia, anticoagulant and bleeding in these patients are summarized in Table V.

\footnotetext{
5 In this patient repetition of studies was prevented by the ephemeral nature of the anticoagulant. Tests performed shortly after admission, when he was acutely ill gave results shown in Figures 1 and 3 and Tables I, II, III, and IV. However, retest of his blood one week later showed only slight abnormalities in coagulation, and by two weeks after initial studies, the clotting tests were all within normal limits.
} 
TABLE V

Bleeding manifestations in systemic lupus

\begin{tabular}{|c|c|c|c|c|}
\hline Patient & $\begin{array}{c}\text { Duration of } \\
\text { thrombocytopenia }\end{array}$ & $\begin{array}{l}\text { Degree of } \\
\text { bleeding }\end{array}$ & $\begin{array}{c}\text { Anti- } \\
\text { coagu- } \\
\text { lant }\end{array}$ & $\begin{array}{c}\text { Sites of } \\
\text { bleeding }\end{array}$ \\
\hline S. S. & $\begin{array}{l}\text { Transient } \\
\text { (splenectomy) }\end{array}$ & $\begin{array}{c}\text { Severe but } \\
\text { transient }\end{array}$ & No & Skin, Uterus \\
\hline M. M. & Prolonged & Prolonged & Yes & $\begin{array}{l}\text { Skin, Nose } \\
\text { Buccal Mucosa }\end{array}$ \\
\hline R. S. & Until death & Fatal & Yes & $\begin{array}{l}\text { Skin, G. I. Nose } \\
\text { ? Lungs }\end{array}$ \\
\hline E. L. & Transient & Prolonged & Yes & Skin, Nose \\
\hline
\end{tabular}

In only one patient (E. L.) was there a hemorrhagic diathesis which could be attributed unequivocally to the presence of circulating anticoagulant. Thus the clotting disorder observed has a low order of clinical significance insofar as bleeding manifestations are concerned.

It would appear to be somewhat more important as confirmatory evidence of the diagnosis of systemic lupus erythematosus. Anomalies of clotting strictly comparable to these found in 10 of these patients have not been observed with any considerable frequency in any other disease. The literature contains reports of 33 cases of naturally occurring circulating anticoagulants. These fall into three large groups as follows:

1. Patients with congenital hemophilia who become resistant to therapy and are found to have developed an ability to neutralize anti-hemophilic globulin.

2. Young women (usually post-partum) who develop a hemorrhagic diathesis associated with prolonged clotting time and the presence of a circulating substance which can neutralize antihemophilic globulin.

3. A heterogeneous group of patients with acquired hemorrhagic tendencies, in whom the circulating anticoagulants appear to operate at different levels of the clotting mechanism.

Among these cases are six in which the anticoagulant was shown to act on the second stage of the coagulation process. The two cases of Conley and Hartmann (1) have already been cited. Cohen, Bonnin, and Hicks (13) have studied another such case extensively. Since completion of our studies, Frick (14) has published reports of three cases of "collagen disease" with circulating anticoagulants; two of these patients had systemic lupus erythematosus, while the third was suffering from hypersensitivity to penicillin. To these six, the present series adds five cases and another five probable (mild) cases.

All but one of these patients had systemic lupus. The apparent exception (case 2 of Frick) was a case of penicillin hypersensitivity ; in this connection it should be noted that 1) a search for L. E. cells was not made, and 2) Walsh and Zimmerman (15) have reported a lupus-like picture (including L. E. cells) in three cases of penicillin hypersensitivity.

If discussion be limited to patients with clinically apparent clotting disorders, six of seven so far reported with a second-stage anticoagulant had systemic lupus erythematosus. This represents a fairly high degree of specificity (which becomes even higher if one accepts the possible identity of certain penicillin reactions with systemic lupus).

Nine of the ten patients in the present series, however, did not have clinically evident clotting abnormality; the disorder was discovered only because a systematic study was performed on every patient with a positive L. E. cell test. Similar studies have been performed, to date, on 75 control subjects, including normals, and patients with periarteritis nodosa, scleroderma, penicillin reaction, rheumatic fever, rheumatoid arthritis, carcinomatosis, leukemia, and chronic nephritis. A clotting pattern similar to that described here has been found in none of these. This does not establish the specificity of this pattern for systemic lupus erythematosus; the number of controls is too small. However, the finding of this pattern in a patient whose diagnosis is obscure must be considered as evidence for lupus.

The two remaining patients of this series showed the presence of circulating anticoagulant differing slightly from the rest. It is possible that these differences were caused by technical factors; observations on both J. I. and B. L. were unfortunately limited.

\section{Theoretical considerations}

Some evidence of the presence of an excess of anticoagulant in the blood appears, in this series, in about 28 per cent of patients with systemic lupus erythematosus, and probably, then, represents a feature of the disease. At least three other 
anomalies of the plasma proteins occur with some frequency in this disease: (a) The L. E. cell factor, an abnormal constituent of the gamma globulin, present almost universally $(16-18)$; (b) a protein capable of reacting with the phospholipids used as antigens in the standard serological tests for syphilis-this is also a constituent of the gamma globulin (19) and is present in 30 to 40 per cent of patients (20) ; and (c) a protein capable of reacting with red blood cells-this is also presumably a gamma globulin, since it produces a positive direct anti-globulin test, and is variously reported as being present in from 25 to 100 per cent of patients $(21,22)$.

The relationship of these four abnormal proteins to each other and to the disease process is, so far, obscure. A theory which has attracted many writers holds that systemic lupus is a disease of hypersensitivity; in line with this theory all the abnormal proteins found in the disease might be regarded as aberrant antibodies- respectively, to leukocytes or specific leukocyte constituents, to phospholipids, and to red blood cells. In the same way, anticoagulant substances might be antibodies to various normally present coagulation factors.

Another hypothesis of the pathogenesis of the disease stems from its practically universal association with one of these abnormal proteins-the L. E. cell factor-and from evidence that many of the anatomic lesions of the disease can be related to known effects of the L. E. cell factor $(23,24)$. According to this theory, presence of the L. E. cell factor would in some way be necessary for the initiation of the disease process. Other abnormal protein activities, occurring with less frequency, might then represent cross-reactions of the $\mathrm{L}$. E. cell factor, detectable in some cases but not in others because of quantitative differences; or they might represent products of the disturbed metabolism.

Anticoagulant activity, directed against thromboplastin, could be an effect of the $\mathrm{L}$. E. cell factor itself. This factor has been shown to require, for its action on leukocytes, the intervention of a substance derived (at least partially) from platelets, and possibly related to thromboplastin (3). If the reaction between the L. E. cell factor and leukocytes bound thromboplastin so as to prevent its reaction with other clotting factors, the L. E. cell factor would then, in effect, be an anticoagulant.

This theory provided part of the impetus for the present study. The finding that over 20 per cent of patients whose blood contains the L. E. cell factor have detectable circulating anticoagulants directed against thromboplastin activity seems to support this hypothesis. However, anticoagulants of the types found in patients J. I. and B. L. cannot be explained on this basis.

Furthermore, if the L. E. cell factor and the anticoagulant were indeed identical, the ability of a patient's serum to produce L. E. cells under optimal conditions ought to be roughly proportional to the anticoagulant activity of his plasma. It is extremely difficult to quantitate L. E. cell factor activity with any degree of accuracy or reproducibility. To the extent to which this was possible (using previously published methods [5]), the L. E. cell-producing-potential of a serum bore no relationship to the anticoagulant activity of blood from the same patient.

At the present time then, the pathogenesis of abnormal blood coagulation in systemic lupus erythematosus is unexplained.

\section{SUMMARY}

The blood coagulation mechanism has been studied in a series of 43 consecutive patients with systemic lupus erythematosus whose blood contained the L. E. cell factor.

Twelve of the 43 showed significant aberration of blood clotting. In seven of these, excess of an anticoagulant substance was demonstrated. The abnormalities in the five remaining patients were similar to, but of lesser degree than those found in the seven patients with demonstrable anticoagulant.

The pattern of abnormal coagulation in systemic lupus is as follows: 1) Slightly prolonged whole blood clotting time; 2 ) prolonged clotting time of platelet-poor recalcified plasma; 3) prolonged one-stage prothrombin time; 4) delayed thrombin generation but normal prothrombin consumption after one hour; 5) the presence of a substance capable of delaying the clotting time of normal blood or plasma.

In ten of the twelve patients the abnormal coagulation could be ascribed to a substance which 
interfered with the action of thromboplastin, but not with the formation of thromboplastin. In one patient impaired generation of thromboplastin was found, with no interference with the action of preformed thromboplastin. In the twelfth patient, it could not be determined whether the anticoagulant activity was due to an anti-thromboplastin or an anti-thrombic substance.

The clinical significance of this clotting disorder is not great. In only 3 of the 12 affected patients was hemorrhage a prominent symptom, and in only one could the bleeding be ascribed solely to the anticoagulant activity. However, the type of clotting disorder found in 10 patients in this series seems to have a high degree of specificity for systemic lupus erythematosus.

The possible relationship of these findings to the pattern of abnormal protein metabolism in systemic lupus has been discussed.

\section{REFERENCES}

1. Conley, C. L., and Hartmann, R. C., A hemorrhagic disorder caused by circulating anticoagulant in patients with disseminated lupus erythematosus. J. Clin. Invest., 1952, 31, 621.

2. Conley, C. L., Disorders of the blood in disseminated lupus erythematosus. Am. J. Med., 1952, 13, 1.

3. Lee, S. L., Schwartz, L. I., and Pariser, S., Blood coagulation and the $\mathrm{L}$. E. cell phenomenon. Blood, 1954, 9, 965.

4. Lee, S. L., A simple test for L. E. cells. Am. J. Clin. Path., 1951, 21, 492.

5. Kurnick, N. B., Schwartz, L. I., Pariser, S., and Lee, S. L., A specific inhibitor for human desoxyribonuclease and an inhibitor of the lupus erythematosus cell phenomenon from leucocytes. J. Clin. Invest., 1953, 32, 193.

6. Ottenberg, R., and Rosenthal, N., A new and simple method for counting blood platelets. J. A. M. A., 1917, 69, 999.

7. Quick, A. J., The Physiology and Pathology of Hemostasis. Philadelphia, Lea \& Febiger, 1951, p. $108,125$.

8. Stefanini, M., and Crosby, W. H., The one-stage prothrombin consumption test; clinical value in the identification of thromboplastin-deficiency diseases. Blood, 1950, 5, 964.
9. Pitney, W. R., and Dacie, J. V., A simple method of studying the generation of thrombin in recalcified plasma. J. Clin. Path., 1953, 6, 9.

10. Svensson, H., Fractionation of serum with ammonium sulfate and water dialysis, studied by electrophoresis. J. Biol. Chem., 1941, 139, 805.

11. Biggs, R., and Douglas, A. S., The thromboplastin generation test. J. Clin. Path., 1953, 6, 23.

12. Alexander, B., Goldstein, R., Rich, L., Le Bolloc'h, A. G., Diamond, L. K., and Borges, W., Congenital afibrinogenemia; a study of some basic aspects of coagulation. Blood, 1954, 9, 843.

13. Cohen, A. K., Bonnin, J. A., and Hicks, N. D., Thrombocytopenic purpura and coagulation defects in a case of systemic lupus erythematosus. Lancet, In press.

14. Frick, P. G., Acquired circulating anticoagulants in systemic "collagen disease." Blood, 1955, 10, 691.

15. Walsh, J. R., and Zimmerman, H. J., The demonstration of the "L.E." phenomenon in patients with penicillin hypersensitivity. Blood, 1953, 8, 65 .

16. Haserick, J. R., Lewis, L. A., and Bortz, D. W., Blood factor in acute disseminated lupus erythematosus. 1. Determination of gamma globulin as specific plasma fraction. Am. J. M. Sc., 1950, 219, 660.

17. Berman, L., Axelrod, A. R., Goodman, H. L., and McClaughry, R. I., So-called "Lupus erythematosus inclusion phenomenon" of bone marrow and blood. Am. J. Clin. Path., 1950, 20, 403.

18. Lee, S. L., Michael, S. R., and Vural, I. L., The L. E. (lupus erythematosus) cell. Am. J. Med., 1951, 10, 446.

19. Coburn, A. F., and Moore, D. H., The plasma proteins in disseminated lupus erythematosus. Bull. Johns Hopkins. Hosp., 1943, 73, 196.

20. Dubois, E. L., Simplified method for the L. E. cell test. Arch. Int. Med., 1953, 92, 168.

21. Dubois, E. L., Acquired hemolytic anemia as the presenting syndrome of lupus erythematosus disseminatus. Am. J. Med., 1952, $12,197$.

22. Wiener, A. S., and Gordon, E. B., Quantitative test for antibody-globulin coating human blood cells, and its practical applications. Am. J. Clin. Path., 1953, 23, 429.

23. Klemperer, P., Gueft, B., Lee, S. L., Leuchtenberger, C., and Pollister, A. W., Cytochemical changes of acute lupus erythematosus. Arch. Path., 1950, 49, 503.

24. Gueft, B., and Laufer, A., Further cytochemical studies in systemic lupus erythematosus. Arch. Path., 1954, 57, 201. 